\title{
In vitro seed germination and seedling performance of Hibiscus coddii subsp. barnardii
}

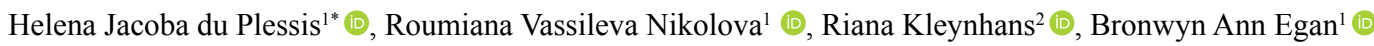 \\ ${ }^{1}$ University of Limpopo, Department of Biodiversity, Private Bag X1106, Sovenga, South Africa \\ ${ }^{2}$ Tshwane University of Technology, Department of Horticulture, Private Bag X680, Pretoria, South Africa
}

\begin{abstract}
Hibiscus coddii subsp. barnardii is an endemic South African plant species with ornamental potential. The limited plant availability in nature and restrictions on the collection of living plant material (cuttings) for cultivation purposes, necessitated the development of a protocol for in vitro seed propagation to ensure all year round ex vitro establishment of plants. The effect of culture medium on seed germination and seedling performance was therefore studied. Various types of sterile seed cultures, namely moist filter paper bridges, five different strengths $\left(1 / 4,1 / 2,3 / 4\right.$, full, 1 1/4) of PGR-free Murashige and Skoog medium (MS) and solid Gelrite ${ }^{\circledR}$ medium (control) were investigated. High germination percentages (85\%-98\%) were found in all three seed cultures, although seeds germinated on filter paper, Gelrite ${ }^{\circledR}$ and lower strengths $(1 / 4,1 / 2,3 / 4)$ of MS medium had shorter mean germination times (1.6-2.8 days) than those germinated on full and 11/4 strengths (3.5-4 days) of MS medium. Furthermore, the growth performance of seedlings varied with the strength of MS medium and was best supported on full strength MS medium, whereas $1 / 4$ and $1 / 2$ strength MS media and Gelrite ${ }^{\circledR}$ cultures were detrimental for seedling growth.
\end{abstract}

Keywords: Hibiscus coddii subsp. barnardii, in vitro grown seedlings, in vitro seed culture, Filter paper bridges, Gelrite ${ }^{\circledR}$ medium, Murashige and Skoog medium.

\section{Resumo}

Germinação de sementes in vitro e performance de mudas de Hibiscus coddii subsp. barnardii

Hibiscus coddii subsp. barnardii é uma espécie endêmica da África do Sul com potencial ornamental. A disponibilidade limitada de plantas na natureza e as restrições à coleta de material vegetal vivo (estacas) para fins de cultivo, exigiram o desenvolvimento de protocolo para a propagação de sementes in vitro para garantir o estabelecimento ex vitro de plantas durante todo o ano. $\mathrm{O}$ efeito do meio de cultura na germinação das sementes e no desempenho das plântulas foi, portanto, estudado. Vários tipos de culturas de sementes estéreis, nomeadamente pontes de papel de filtro úmido, cinco dosagens diferentes $(1 / 4,1 / 2,3 / 4$, completo, 11/4) de meio Murashige e Skoog sem PGR (MS) e meio Gelrite ${ }^{\circledR}$ sólido (controle) foram investigados. Altas porcentagens de germinação (85\%-98\%) foram encontradas em todas as três culturas de sementes, embora as sementes germinaram em papel de filtro Gelrite ${ }^{\circledR}$ e dosagens mais baixas $(1 / 4,1 / 2,3 / 4)$ do meio MS tiveram tempos médios de germinação mais curtos $(1,6-2,8$ dias $)$ do que aqueles germinados em doses totais e 11/4 (3,5-4 dias) de meio MS. Além disso, o desempenho de crescimento das mudas variou com a resistência do meio MS e foi melhor suportado no meio MS de força total, enquanto os meios MS de força $1 / 4$ e $1 / 2$ e culturas Gelrite ${ }^{\circledR}$ foram prejudiciais para o crescimento das mudas.

Palavras-chave: Hibiscus coddii subsp. barnardii, mudas cultivadas in vitro, cultura de sementes in vitro, pontes de papel de filtro, meio Gelrite ${ }^{\circ}$, meio Murashige e Skoog.

\section{Introduction}

Hibiscus coddii Exell subsp. barnardii (Exell) Leistner \& P.J.D. Winter (family Malvaceae) is an endemic South African flowering plant species with the commercial potential to be grown as an ornamental pot plant or in rockeries in drought-prone areas (Craib, 2003). Successful propagation and multiplication of this plant are, however, imperative for its introduction into the horticultural market. Propagation of ornamental plants is mainly by means of seeds, cuttings, and in vitro culture (Davies et al., 2017). Collection of living plant material (cuttings) from wild

*Corresponding author: E-mail: helena.duplessis@ul.ac.za 
H. coddii subsp. barnardii plants for propagation purposes is, however, restricted. This necessitated the development of a protocol for seed propagation to generate stock plants.

Our previous study on in vivo seed germination, showed that scarification of the small, hard seeds of $H$. coddii subsp. barnardii with $98 \%$ sulfuric acid $\left(\mathrm{H}_{2} \mathrm{SO}_{4}\right)$ for $30 \mathrm{~min}$ can uplift physical dormancy resulting in high (80\%-90\%) germination percentages (Du Plessis et al., 2019). However, the in vivo seed cultures required constant care and maintenance of adequate moisture to ensure good germination performance. On the other hand, germination of seeds in the closed environment of in vitro cultures can provide constant moisture levels, resulting in fast germination and more uniform seedlings (Roni et al., 2018). Seedlings derived from in vitro germinated seeds can be used as an aseptic explant source for in vitro multiplication of valuable plants as reported for $H$. cannabinus (Sultana et al., 2016), H. sabdariffa (Kumar et al., 2016) and H. syriacus (Seo et al., 2017). Ayadi et al. (2011) and Samanthi et al. (2013) noted high germination $(90 \%-100 \%)$ within two to three days when scarified seeds of $H$. cannabinus were cultured in vitro on full strength Murashige and Skoog (MS) medium, although further development of these in vitro seedlings were not reported. However, Daffalla et al. (2016) described both the germination and seedling development of scarified seeds of Grewia tenax (Malvaceae) on two strengths ( $1 / 2$ and full) of MS medium.

To the best of our knowledge, there is no available information for in vitro propagation of $H$. coddii subsp. barnardii. The purpose of this research was therefore to establish optimal conditions for in vitro seed germination and seedling development based on the responses to various seed cultures and growth media compositions. This is also required to provide seedling material that can serve as an aseptic explant source for shoot multiplication and for all year round ex vitro establishment of plants.

\section{Materials and methods}

\section{Plant material}

The open flowers of mature $H$. coddii subsp. barnardii plants grown in a greenhouse were hand-pollinated and 80-90 fruit capsules, each containing 10-15 seeds, were collected. Seeds were removed from the capsules and used to study the in vitro germination response in different seed cultures.

\section{Seed germination}

Seed scarification and disinfection

Seeds were scarified with $98 \% \mathrm{H}_{2} \mathrm{SO}_{4}$ for $30 \mathrm{~min}$ (Du Plessis et al., 2019) and then surface disinfected with $70 \%\left(\mathrm{v} \mathrm{v}^{-1}\right)$ ethanol for $90 \mathrm{~s}$ followed by $50 \%$ (v $\left.\mathrm{v}^{-1}\right)$ commercial bleach solution $[1.75 \%$ active sodium hypochlorite $(\mathrm{NaOCl})$ ], with 2-3 drops of Tween 20 , for 25 min (Sekhukhune et al., 2018). The seeds were rinsed three times with sterile distilled water after each disinfection step to remove the disinfectant.

\section{Culture media}

Five different strengths $[1 / 4,1 / 2,3 / 4$, full (1), 11/4] of MS basal medium (Murashige and Skoog, 1962) varying in the macronutrient, micronutrient, iron source, and vitamin concentration, were used. Each medium was supplemented with $3 \%$ sucrose and $0.3 \%\left(\mathrm{w} \mathrm{v} \mathrm{v}^{-1}\right)$ Gelrite ${ }^{\circledR}$ (Franklin and Dixon, 1994). A solid medium containing only $1.2 \%\left(\mathrm{~W} \mathrm{v}^{-1}\right)$ Gelrite ${ }^{\circledR}$, dissolved in distilled water, served as control. The media ( $\mathrm{pH}$ 5.8) were dispensed into Magenta ${ }^{\mathrm{TM}}$ B-cap glass culture vessels and autoclaved at $121^{\circ} \mathrm{C}$ for $20 \mathrm{~min}$.

\section{Seed cultures}

Disinfected seeds were inoculated on three types of culture media, namely moist filter paper bridges placed in Magenta ${ }^{\mathrm{TM}} \mathrm{B}$-cap glass culture vessels layered with distilled water, a semi-solid PGR-free MS medium of five different strengths $[1 / 4,1 / 2,3 / 4$, full (1), 11/4], and a solid medium containing $1.2 \%\left(\mathrm{~W} \mathrm{~V}^{-1}\right)$ Gelrite ${ }^{\circledR}$ that served as the control.

\section{Seedling performance}

Seeds germinated on filter paper bridges were aseptically transferred after radicle protrusion (1-2 mm) to $1 / 2$ and full strength MS medium for further seedling development. Seeds germinated directly in the different strengths of MS media and in the Gelrite ${ }^{\circledR}$ medium (control) remained in the culture bottles for further seedling development.

\section{Growth conditions}

All in vitro seed cultures and seedlings were kept in a growth room under controlled conditions at $24 \pm 2{ }^{\circ} \mathrm{C}$ with a 16-h photoperiod at $55-60 \mu \mathrm{mol} \mathrm{m} \mathrm{m}^{-2} \mathrm{~s}^{-1}$ provided by a mixture of cool-white (Phillips and Osram) and Gro-lux (Sylvania) fluorescent tubes.

\section{Acclimatization and hardening-off of seedlings}

In vitro produced seedlings (5-6 weeks old) were removed from the culture vessels and the excess MS medium was carefully washed from the roots with tap water. The seedlings were planted in plastic pots filled with moist vermiculite and covered with perforated transparent plastic bags in the first few weeks. This allowed for gradual exposure from high humidity conditions in the culture vessel to a lower humidity and high light intensity in the open environment. Bags were completely removed after 2-3 weeks and seedlings were transferred to a mixture of potting soil, vermiculite and sand $[5: 3: 1(\mathrm{v} / \mathrm{v} / \mathrm{v})]$ for a further $1-2$ weeks. Acclimatization of seedlings was done under controlled conditions in a growth room at $24 \pm 2{ }^{\circ} \mathrm{C}$ with a $16-\mathrm{h}$ photoperiod at $150-200 \mu \mathrm{mol} \mathrm{m} \mathrm{m}^{-2} \mathrm{~s}^{-1}$ provided by a mixture of cool-white (Phillips and Osram) and Grolux (Sylvania) fluorescent tubes. Acclimatized seedlings were hardened-off in a greenhouse under uncontrolled environmental conditions. Seedlings were watered with tap water three times per week and received a watersoluble fertilizer containing macro- and micronutrients once per week. Further development and survival of mature plants was monitored for 12 weeks. 


\section{Experimental design}

The seed germination experiment on filter paper bridges had three replicates with 120 seeds each, where 10 seeds per culture bottle served as the experimental unit. Cultures for seedling development on $1 / 2$ and full strength MS media (after subculture from filter paper) was a pair-wise design with 60 replicates with one seedling in a culture bottle being the experimental unit. Seed germination and seedling development on different strengths of MS media followed a randomized complete block design with six treatments $\left[1 / 4,1 / 2,3 / 4\right.$, full, and $1 \frac{1 / 4}{4}$ strength of MS media and Gelrite ${ }^{\circledR}$ (control)] replicated four times. The experimental unit was 10 seeds per treatment.

\section{Data collection and statistical analysis}

In all the seed cultures, germination was regarded as protrusion of the radicle $(1-2 \mathrm{~mm})$ through the seed coat (Davies et al., 2017) and was recorded daily until no further germination was observed (14 d). Germination responses were evaluated by assessing the following germination parameters: final germination percentage (FGP), mean germination time (MGT) and germination rate index (GRI) (Younesikelaki et al., 2016).

The performance of seedlings derived from the different seed cultures was evaluated with respect to growth, survival and morphology for a period of up to five weeks in order to select the best culture medium for in vitro seedling growth. The number of nodes on the main stem of the seedlings was counted weekly over a period of five weeks, whilst the seedlings remained in the culture bottles (non-destructive method). The number of surviving seedlings was recorded after five weeks. Visible qualitative changes in the morphological appearance of seedlings developed on the different strengths of MS media and Gelrite $\left({ }^{\circledR}\right.$ cultures were also monitored and photographed weekly for five weeks.

Data were analyzed with the $\mathrm{SAS} \otimes$ Version 9.3 statistical software and subjected to analysis of variance (ANOVA) using the linear models procedure (PROC GLM). The means of the treatments were separated with T test (LSD) at the 5\% level of significance. The ShapiroWilk's test was performed on the standardized residuals to test for deviations from normality.

\section{Results and Discussion}

The method used for surface disinfection of chemically scarified seeds of $H$. coddii subsp. barnardii proved effective for establishment of aseptic conditions for in vitro germination in all seed cultures since no microbial contaminations were observed. Similar seed disinfection procedures with ethanol (70\%-100\%) and $\mathrm{NaOCl}(20 \%-50 \%)$ were also used for other Hibiscus species (Sakhanokho and Kelley, 2009; Ayadi et al., 2011; Samanthi et al., 2013).

\section{Seed germination}

Germination of $H$. coddii subsp. barnardii seeds in all three cultures, filter paper bridges, various strengths of MS media and Gelrite $\AA$, started from 1-2 d after inoculation. The ANOVA analysis showed no statistical differences between the three different cultures for any of the germination parameters (FGP, MGT, and GRI) (Table 1). However, significant differences were observed among the different strengths of MS media and the Gelrite ${ }^{\circledR}$ cultures with respect to the MGT and the GRI (Table 1).

Table 1. In vitro germination responses of $H$. coddii subsp. barnardii seeds on various aseptic seed cultures.

\begin{tabular}{|c|c|c|c|}
\hline & \multicolumn{3}{|c|}{ Germination parameters } \\
\hline & FGP & MGT & GRI \\
\hline \multirow{2}{*}{ Seed culture } & $(\%)$ & (days) & (No. of germinated \\
\hline & & & seeds/day) \\
\hline Filter paper bridges & $96.40 \pm 1.28$ & $1.78 \pm 0.46$ & $6.71 \pm 1.53$ \\
\hline MS culture medium & FGP & MGT & GRI \\
\hline \multirow[t]{2}{*}{ (various strengths) } & $(\%)$ & (days) & (No. of germinated \\
\hline & & & seeds/day) \\
\hline $1 / 4 \mathrm{MS}$ & $95.0 \pm 5.77 \mathrm{a}$ & $1.72 \pm 0.35 \mathrm{a}$ & $6.67 \pm 1.52 \mathrm{ab}$ \\
\hline $1 / 2 \mathrm{MS}$ & $97.50 \pm 5.0 \mathrm{a}$ & $2.17 \pm 0.98 \mathrm{ab}$ & $6.0 \pm 2.37 b$ \\
\hline $3 / 4 \mathrm{MS}$ & $97.50 \pm 5.0 \mathrm{a}$ & $2.83 \pm 0.96 \mathrm{abc}$ & $5.34 \pm 1.87 \mathrm{bc}$ \\
\hline Full MS & $95.0 \pm 10.0 \mathrm{a}$ & $3.47 \pm 1.63 \mathrm{bc}$ & $4.60 \pm 1.57 \mathrm{~cd}$ \\
\hline $11 \frac{1}{4} \mathrm{MS}$ & $85.0 \pm 12.9 a$ & $4.0 \pm 2.46 \mathrm{c}$ & $3.60 \pm 2.19 d$ \\
\hline Gelrite ${ }^{\circledR}(1.2 \%)$ & $97.50 \pm 5.0 \mathrm{a}$ & $1.55 \pm 0.54 \mathrm{a}$ & $7.74 \pm 1.52 \mathrm{a}$ \\
\hline F pr. & 0.282 & 0.008 & 0.000 \\
\hline LSD & - & 1.35 & 1.36 \\
\hline F pr. & $0.257^{*}$ & $0.097^{*}$ & $0.074^{*}$ \\
\hline
\end{tabular}

Means \pm standard deviation within a column followed by the same letter are not significantly different at the $5 \%$ level of significance. FGP: final germination (\%), MGT: mean germination time, GRI: germination rate index, F pr.: F probability, LSD: least significant difference. *Indicates no significant differences between the three seed cultures. 
Seeds of $H$. coddii subsp. barnardii showed high (85\%-97.5\%) FGPs in all three seed cultures (Table 1). Ayadi et al. (2011) also reported high germination (100\%) within 2-3 d when scarified seeds of H. cannabinus were germinated on full strength MS medium. Furthermore, Daffalla et al. (2016) reported 100\% germination of $G$. tenax seeds within $14 \mathrm{~d}$ when cultured on water agar and $1 / 2$ and full strength MS media. Contrary to the high FGPs recorded for $H$. coddii subsp. barnardii seeds on $1 / 2(97.5 \%)$ and full (95\%) strengths of MS media (Table 1), Gupta et al. (2017) only reported $24 \%$ and $17 \%$ germination of Gymnocladus assamicus seeds on $1 / 2$ and full strength MS media, respectively. Similarly, only $38 \%$ of Ficus religiosa seeds germinated on full strength MS medium (Hesami et al., 2018). The low germination percentages recorded in these studies were ascribed to possible impurities in the agar or sensitivity of the seeds to the high salt content of the MS medium (Gupta et al., 2017; Hesami et al., 2018).

The lowest MGT $(1.55 \mathrm{~d})$ for $H$. coddii subsp. barnardii seeds was recorded on the Gelrite ${ }^{\circledR}$ culture, which differed significantly from the MGT for seeds on full and $1 \frac{1}{4}$, but not from $1 / 4,1 / 2$, and $3 / 4$ strengths of MS media (Table 1). Daffalla et al. (2016) also reported a faster germination time for $G$. tenax seeds placed on water agar (control medium) which differed significantly from the MGT on full strength, but not from $1 / 2$ strength MS medium. The MGT for $H$. coddii subsp. barnardii seeds increased with an increase in the strength of MS medium. Seeds cultured on $1 / 4,1 / 2$, and $3 / 4$ strengths germinated faster than seeds on full MS and significantly faster than seeds on $1 \frac{1}{4}$ strength of MS medium (Table 1). Seeds of G. tenax on $1 / 2$ strength MS medium also germinated significantly faster $(4.8 \mathrm{~d})$ than the seeds on full strength medium $(6.2$ d) (Daffalla et al., 2016). This might suggest that a lack or lower concentration of macro- and microelements is not detrimental to seed germination and that the good germination response of $H$. coddii subsp. barnardii seeds was mainly related to water availability as also reported by Koné et al. (2015) for Vigna subterreana. The delay in germination of $H$. coddii subsp. barnardii seeds cultured on full and $1 \frac{1 / 4}{4}$ strength of MS media could be ascribed to the higher salt concentration in MS medium as compared to other culture media with a lower salt content used for in vitro seed germination (Araruna et al., 2017; Davies et al., 2017). Solanki and Siwach (2012) observed no germination when seeds of Aconitum heterophyllum were cultured on cotton wool moistened with MS medium or on solid MS medium, and seeds only germinated on cotton wool moistened with distilled water.

A significantly higher number of seeds germinated per day on $1 / 4$ and $1 / 2$ MS media strengths than on full and $1 \frac{1 / 4}{4}$ strengths of MS media (Table 1). The highest GRI ( 7.74 seeds $\left.\mathrm{d}^{-1}\right)$ was obtained for the Gelrite ${ }^{\circledR}$ culture that differed significantly from the GRI for all strengths of MS media except the $1 / 4$ strength (Table 1). Likewise, Daffalla et al. (2016) reported that culturing seeds of G. tenax on water agar medium with no added nutrients accelerated the germination rate.

\section{Seedling performance}

Seedlings derived from seeds germinated on filter paper

Seeds germinated on filter paper bridges (Figure 1A) developed into seedlings two weeks after transfer to $1 / 2$ and full strengths of MS media.

The ANOVA analysis showed that the medium strength did not have a significant effect on the number of nodes and the survival percentage of these seedlings from week 2-5 (Table 2A). The seedlings in both strengths of MS media cultures showed an increase in the number of nodes (3 to 9) on the main stem over a period of five weeks and attained a high survival percentage (98.3\%) after five weeks (Table 2A). 
Table 2. The number of nodes and survival percentage of seedlings developed from (A) Seeds germinated on filter paper and transferred to $1 / 2$ and 1 (full) strength MS medium and from (B) Seeds germinated directly on different strengths of MS medium and on Gelrite.

A. Seedlings developed from seeds germinated on filter paper and transferred to $1 / 2$ and

\begin{tabular}{|c|c|c|c|c|c|}
\hline \multicolumn{6}{|c|}{ full strength MS medium } \\
\hline \multirow[b]{2}{*}{ Treatment } & \multicolumn{4}{|c|}{ Number of nodes } & \multirow{2}{*}{$\begin{array}{c}\text { Survival \% } \\
\text { Week } 5\end{array}$} \\
\hline & Week 2 & Week 3 & Week 4 & Week 5 & \\
\hline $1 / 2 \mathrm{MS}$ & $3.50 \pm 0.20 \mathrm{a}$ & $5.96 \pm 0.27 \mathrm{a}$ & $7.60 \pm 0.20 \mathrm{a}$ & $9.17 \pm 0.31 \mathrm{a}$ & $98.33 \pm 4.08 \mathrm{a}$ \\
\hline Full MS & $3.12 \pm 0.44 a$ & $5.62 \pm 0.25 \mathrm{a}$ & $7.13 \pm 0.44 a$ & $8.87 \pm 0.43 \mathrm{a}$ & $98.33 \pm 4.08 \mathrm{a}$ \\
\hline \multirow[t]{3}{*}{ F pr. } & 0.063 & 0.135 & 0.190 & 0.446 & 0.753 \\
\hline & \multicolumn{5}{|c|}{ B. Seedlings developed from seeds germinated directly on MS medium and on Gelrite } \\
\hline & \multicolumn{4}{|c|}{ Number of nodes } & Survival \% \\
\hline Treatment & Week 2 & Week 3 & Week 4 & Week 5 & Week 5 \\
\hline $1 / 4 \mathrm{MS}$ & $3.32 \pm 0.11 \mathrm{a}$ & $5.79 \pm 0.18 \mathrm{a}$ & $7.22 \pm 0.30 \mathrm{a}$ & $8.48 \pm 0.50 \mathrm{a}$ & $86.33 \pm 15.18 b$ \\
\hline $1 / 2 \mathrm{MS}$ & $3.29 \pm 0.24 \mathrm{a}$ & $5.39 \pm 0.18 \mathrm{ab}$ & $6.94 \pm 0.44 a$ & $8.46 \pm 0.31 \mathrm{a}$ & $96.67 \pm 5.77 \mathrm{ab}$ \\
\hline $3 / 4 \mathrm{MS}$ & $3.19 \pm 0.07 \mathrm{ab}$ & $5.04 \pm 0.13 \mathrm{bc}$ & $6.68 \pm 0.19 \mathrm{ab}$ & $8.42 \pm 0.19 \mathrm{a}$ & $100.0 \pm 0.0 \mathrm{a}$ \\
\hline Full MS & $2.78 \pm 0.11 \mathrm{c}$ & $4.43 \pm 0.28 \mathrm{~d}$ & $6.04 \pm 0.39 \mathrm{~b}$ & $7.67 \pm 0.45 b$ & $100.0 \pm 0.0 \mathrm{a}$ \\
\hline $1 \frac{1}{4} \mathrm{MS}$ & $2.90 \pm 0.33 b c$ & $4.51 \pm 0.65 \mathrm{~cd}$ & $6.16 \pm 0.47 b$ & $7.80 \pm 0.37 \mathrm{ab}$ & $100.0 \pm 0.0 \mathrm{a}$ \\
\hline Gelrite ${ }^{\circledR}$ & $1.37 \pm 0.06 \mathrm{~d}$ & $2.20 \pm 0.17 \mathrm{e}$ & $2.33 \pm 0.35 \mathrm{c}$ & $2.33 \pm 0.35 c$ & $0.0 \pm 0.0 \mathrm{c}$ \\
\hline$F p r$. & $<.0001$ & $<.0001$ & $<.0001$ & $<.0001$ & $<.0001$ \\
\hline LSD & 0.32 & 0.59 & 0.68 & 0.74 & 12.18 \\
\hline
\end{tabular}

Means \pm standard deviation within a column followed by the same letter are not significantly different at the $5 \%$ level of significance. F pr:: F probability, LSD: least significant difference. 

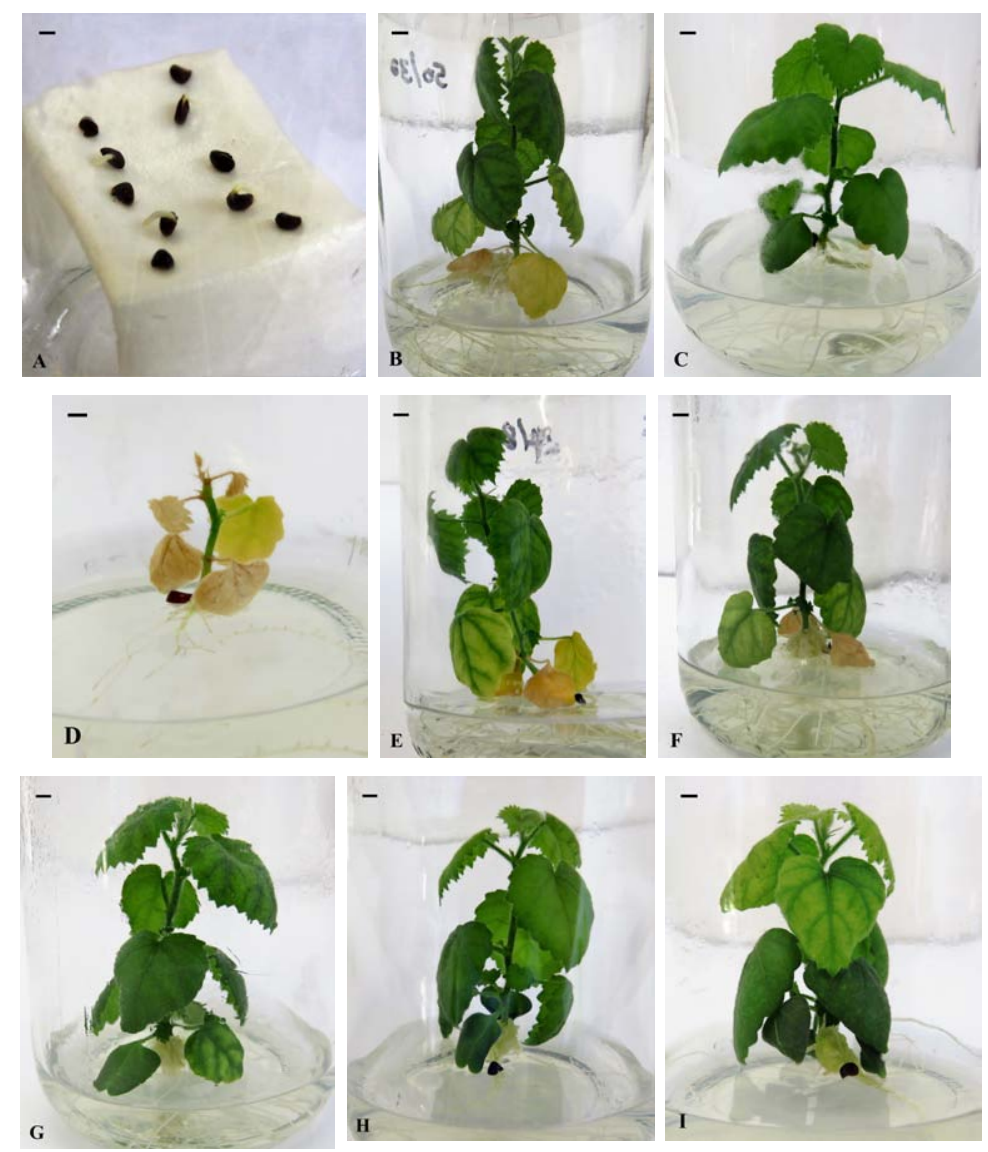

Figure 1. Examples of in vitro seed germination and seedling development of $H$. coddii subsp. barnardii.

(A) Seed germination on filter paper bridges and (B-C) five week old seedlings after subculture of germinated seeds to MS medium: (B) $1 / 2$ strength showing symptoms of interveinal chlorosis in older leaves, (C) full strength with green leaves and well-established root system; (D-I) Five week old seedlings after direct germination of seeds on different culture media: (D) Water-Gelrite $\mathbb{R}$ showing severe senescence symptoms, MS medium (E) $1 / 4$ strength and (F) $1 / 2$ strength showing necrosis of cotyledons and interveinal chlorosis in older leaves, $(G) 3 / 4$ strength with interveinal chlorosis in older leaves and well-established roots, (H) full strength and (I) $1 \frac{1}{4}$ strength with well-developed leaves and interveinal chlorosis in younger leaves. Scale bar: $20 \mathrm{~mm}$.

The cotyledons of seedlings, grown on both $1 / 2$ and full strengths of MS media, appeared in the first week and remained dark green up to the fourth week of culture. Yellowing of the cotyledons was visible in seedlings grown on $1 / 2$ strength MS medium at five weeks (Figure 1B), while it was not observed for those on full strength MS medium (Figure 1C). The first true leaf appeared in the second week on both strengths of MS media. The lower concentration of nutrients in $1 / 2$ strength MS medium had a negative impact on seedling performance, resulting in severe symptoms of interveinal chlorosis after five weeks of culture (Figure 1B). In contrast, full strength MS medium proved suitable for seedling development, since no deficiency symptoms were observed and seedlings remained green (Figure 1C). The taproot developed lateral roots from the second week onwards and a well-developed root system was established on seedlings from both MS medium strengths.

In the present study, it was observed that the faster germination of seeds on filter paper bridges facilitated seedling development after the transfer of germinated seeds on full strength MS medium. Such an approach could be useful for in vitro establishment of seedlings in plant species where it is difficult to germinate seeds directly on tissue culture media. Sekhukhune et al. (2018) reported similar observations for in vitro germination of Actinidia arguta and A. chinensis seeds.

\section{Seedlings derived from seeds germinated directly on} Gelrite ${ }^{\circledR}$ and MS medium

The ANOVA analysis showed that different MS medium strengths and Gelrite ${ }^{\circledR}$ (control) had a significant effect on the number of nodes (week 2-5) of in vitro grown $H$. coddii subsp. barnardii seedlings and on the survival percentage at five weeks. Seedlings showed a progressive increase in the number of nodes on all strengths of MS media over a period of five weeks (Table 2B). The highest average number $(>8)$ of nodes per seedling at week 5 was recorded on the lower $(1 / 4,1 / 2$ and $3 / 4)$ strengths of MS media and the number of nodes on these media was significantly higher than those on full strength MS medium (7.67 nodes) and Gelrite ${ }^{\circledR}$ which had the least number (2.33) of nodes (Table 2B). Two week old seedlings of G. tenax cultured on water 
agar (control) also had the lowest number of nodes, whereas in contrast to our findings, the most nodes were recorded on seedlings cultured on full strength MS medium (Daffalla et al., 2016). Koné et al. (2015) also found that very low concentrations of macro- and micronutrients in $1 / 4$ strength MS medium negatively affected seedling growth (smaller seedlings with less nodes) of $V$. subterreana compared to full strength MS medium.

The MS medium strength and Gelrite ${ }^{\circledR}$ treatment also influenced the survival of $H$. coddii subsp. barnardii seedlings. The best seedling survival (100\%) at week 5 was observed on higher strengths $(3 / 4$, full, and $11 / 4)$ of MS media, while significantly fewer $(86.3 \%)$ seedlings survived on the lowest strength $(1 / 4)$ of MS medium. None of the seedlings on the Gelrite $\AA$ culture survived after five weeks due to the complete lack of nutrients in the medium (Table 2B).

The seed displayed epigeous germination followed by the development of the first true leaves, and a tap- and lateral roots in the first week. Well-developed seedlings, without morphological differences between the treatments, established after two weeks. However, seedlings on the Gelrite ${ }^{\circledR}$ culture showed severe symptoms of senescence from the third week onwards and died after 4-5 weeks (Figure 1D). Although this medium resulted in fast seed germination, it proved detrimental to seedling development, as the lack of essential nutrients prevents plants completing their life cycle (Taiz et al., 2015; Alshaal and El-Ramady, 2017). Koné et al. (2015) also reported the lowest growth performance of $V$. subterreana seedlings grown on a control medium without inorganic salts. Seedlings of $H$. coddii subsp. barnardii grown on lower $(1 / 4$ and $1 / 2)$ strengths of MS media showed yellowing of cotyledons and chlorosis on older leaves (Figure 1E and 1F) which could be due to the lower nutrient concentration in the medium.

Cotyledons of seedlings grown on higher $(3 / 4$, full and $1 \frac{1}{4}$ ) strengths of MS media remained green up to the fifth week (Figure 1G-I), although the appearance of the leaves differed depending on the treatment. Seedlings grown on $3 / 4$ strength of MS medium showed symptoms of interveinal chlorosis on the lower leaves (Figure 1G) at a later stage (week 5) which could be associated with deficiency of essential mobile elements such as $\mathrm{Mg}$ (Taiz et al., 2015; Farhat et al., 2016). Seedlings grown on higher (full and 1/1/4) strengths of MS media had welldeveloped leaves and thicker stems after 5-6 weeks in culture. Symptoms of interveinal chlorosis appeared on the younger leaves of seedlings in both these strengths, but it was more pronounced on the 11/4 strength (Figure 1I). Such symptoms might be associated with deficiency of essential immobile nutrients such as $\mathrm{Fe}$ and $\mathrm{Ca}$ that cannot be readily mobilized from the older leaves (Taiz et al., 2015; Kobayashi et al., 2019). These results show that seedlings cannot be sustained on these media strengths for more than 5-6 weeks and thereafter should be transplanted to a soil culture for acclimatization and further development into mature plants.
Although the best performance in terms of germination parameters of $H$. coddii subsp. barnardii was found for seeds germinated on filter paper, Gelrite $\AA$, and lower $(1 / 4$ and $1 / 2)$ strengths of MS media, these cultures proved unsustainable for in vitro seedling establishment. This shows that the nutritional requirements for initiation of germination are different from those for optimum seedling development, which was also reported by Koné et al. (2015) for $V$. subterreana. However, these types of cultures could be suitable for germination studies as also recommended by Daffalla et al. (2016) for water agar medium. Based on the above results, full strength MS medium was selected as the most suitable for in vitro production of seedlings, which can also serve as an explant source for further in vitro multiplication studies. This is in accordance with research on Hibiscus and other species of the Malvaceae family where full strength MS medium was also used for in vitro seed germination and development of seedlings that were used as an aseptic explant source (Ayadi et al., 2011; Daffalla et al., 2016; Kumar et al., 2016; Sultana et al., 2016).

\section{Acclimatization and hardening-off of seedlings}

Seedlings were successfully acclimatized over a period of 2-3 weeks in moist vermiculite under controlled environmental conditions and exhibited 90\% survival. Further hardening-off of seedlings in a greenhouse (uncontrolled environment) resulted in well-established mature plants (90\% survival) which proved suitable for transplanting to an open environment. Mature plants flowered 2-3 months after the transplant and showed phenotypic similarities with naturally grown plants.

\section{Conclusions}

Aseptic in vitro seed cultures (filter paper, Gelrite ${ }^{\circledR}$ and MS medium) of $H$. coddii subsp. barnardii were successfully established. Seed germination was most successful on moist filter paper bridges, Gelrite ${ }^{\circ}$, and lower $(1 / 4$ and $1 / 2)$ strengths of MS media. However, these seed cultures proved unsustainable for seedling establishment, which was best supported on full strength MS medium. In vitro seed propagation of $H$. coddii subsp. barnardii could be beneficial for faster commercial production of seedlings and plants all year round in a limited space with low maintenance of plant material. In vitro produced seedlings can also serve as an aseptic explant source for in vitro shoot culture and for ex vitro establishment of plants.

\section{Author contribution}

HJdP: performed the idea, experiment development, conduction and evaluation of the experiment, analysis and interpretation of data, writing of the manuscript; RVN: performed the idea, interpretation of data, critical review of the manuscript and made corrections; RK: analysis and interpretation of data, review of the manuscript; BAE: manuscript review and made corrections. 


\section{Acknowledgements}

The authors are grateful for financial support from the National Research Foundation of South Africa (NRF Grant no: 110867) and financial and research support from the University of Limpopo. The authors would like to acknowledge Ms Liesl Morey from the Agricultural Research Council of South Africa for assisting with statistical analyses.

\section{References}

ALSHAAL, T.; EL-RAMADY, H. Foliar application: from plant nutrition to biofortification. Environment, Biodiversity \& Soil Security, v.1, p.71-83, 2017. DOI: https://dx.doi.org/10.21608/jenvbs.2017.1089.1006

ARARUNA, E.C.; OLIVEIRA, J.P.R.; PEREIRA, V.J.; ASMAR, S.A.; MELO, B. Salt concentrations in culture media for the development of Dipteryx alata in vitro. Pesquisa Agropecuária Brasileira, v.52, n.12, p.1295-1300, 2017. DOI: https://doi.org/10.1590/s0100204x2017001200020

AYADI, R.; HAMROUNI, L.; HANANA, M.; BOUZID, S.; TRIFI, M.; KHOUJA, M.L. In vitro propagation and regeneration of an industrial plant kenaf (Hibiscus cannabinus L.). Industrial Crops and Products, v.33, n.2, p.474-480, 2011. DOI: https://doi.org/10.1016/j. indcrop.2010.10.025

CRAIB, C. Hibiscus barnardii: A beautiful Hibiscus from Sekhukhuneland. Veld \& Flora, v.89, n.2, p.64-65, 2003.

DAFFALLA, H.M.; ELSHEIKH, A.M.; ALI, H.A.; KHALFALA, M.M. In vitro seed germination and node culture of the nutraceutical plant Grewia tenax. Environmental and Experimental Biology, v.14, p.7581, 2016. DOI: http://dx.doi.org/10.22364/eeb.14.11

DAVIES, F.T.; GENEVE, R.L.; WILSON, S.B.; HARTMANN, H.T.; KESTER, D.E. Hartmann \& Kester's plant propagation: principles and practices, 9ed. New York: Pearson Education Inc., 2017. 1024p.

DU PLESSIS, H.J.; KLEYNHANS, R.; NIKOLOVA, R.V.; EGAN, B.A. Factors affecting seed propagation of Hibiscus coddii subsp. barnardii: a new potential ornamental plant. Propagation of Ornamental Plants, v.19, n.2, p.38-47, 2019.

FARHAT, N.; ELKHOUNI, A.; ZORRIG, W.; SMAOUI, A.; ABDELLY, C.; RABHI, M. Effects of magnesium deficiency on photosynthesis and carbohydrate partitioning. Acta Physiologiae Plantarum, v.38, n.145, p1-10, 2016. DOI: https://doi.org/10.1007/s11738-016-2165-z
FRANKLIN, C.I.; DIXON, R.A. Initiation and maintenance of callus and cell suspension culture. In: DIXON, R.A.; GONZALES, R.A. (Eds.) Plant Cell Culture: A practical approach, 2ed. New York: Oxford University Press Inc., 1994. p.1-23.

GUPTA, S.; MAO, A.A.; SARMA, S.; SATISH, T. Responses of pretreatment and nutrient media on seed germination in Gymnocladus assamicus, a critically endangered legume tree species from North-East India. Journal of Tree Sciences, v.36, n.1, p.86-92, 2017. DOI: http://dx.doi.org/10.5958/2455-7129.2017.00012.7

HESAMI, M.; DANESHVAR, M.H.; YOOSEFZADEHNAJAFABADI, M. Establishment of a protocol for in vitro seed germination and callus formation of Ficus religiosa L., an important medicinal plant. Jundishapur Journal of Natural Pharmaceutical Products, v.13, n.4, p.1-8, 2018. DOI: https://dx.doi.org/10.5812/jjnpp.62682

KOBAYASHI, T.; NOZOYE, T.; NISHIZAWA, N.K. Iron transport and its regulation in plants. Free Radical Biology and Medicine, v.133, p11-20, 2019. DOI: https://doi. org/10.1016/j.freeradbiomed.2018.10.439

KONÉ, M.; KONÉ, T.; SILUÉ, N.; SOUMAHORO, A.B.; KOUAKOU, T.H. In vitro seed germination and seedling growth of Bambara groundnut (Vigna subterranea (L.) Verdc. (Fabaceae)). The Scientific World Journal, v.2015, p.1-8, 2015. DOI: https://doi.org/10.1155/2015/595073

KUMAR, S.S.; MANOJ, P.; GIRIDHAR, P. Micropropagation for mass multiplication and enriched production of ascorbic acid in tissue culture foliage of roselle (Hibiscus sabdariffa L.) In Vitro Cellular \& Developmental Biology, v.52, p.427-436, 2016. DOI: https://doi.org/10.1007/s11627-016-9785-2

MURASHIGE, T.; SKOOG, F. A revised medium for rapid growth and bioassays with tissue cultures. Physiologia Plantarum, v.15, p.473-497, 1962.

RONI, Z.K.; ISLAM, S.; SHIMASAKI, K. In vitro seed germination and tracking the seedling growth of eustoma.

New Zealand Journal of Crop and Horticultural Science, v.46, n.3, p.224-242, 2018. DOI: https://doi.org/ $10.1080 / 01140671.2017 .1391300$

SAKHANOKHO, H.F.; KELLEY, R.Y. Influence of salicylic acid on in vitro propagation and salt tolerance in Hibiscus acetosella and Hibiscus moscheutos (cv 'Luna Red'). African Journal of Biotechnology, v.8, n.8, p.1474-1481, 2009. 
SAMANTHI, P.W.; MOHD PUAD, A.M.; SUHAIMI, N.; KUMAR, S.M.; NORAINI, A.S. In vitro shoot regeneration from leaf explants of kenaf (Hibiscus cannabinus L.). Sains Malaysiana, v.42, n.10, p.1505-1510, 2013.

SEKHUKHUNE, M.K.; NIKOLOVA, R.V.; MAILA, M.Y. Effect of cold stratification and gibberellic acid on in vitro germination of Actinidia arguta and Actinidia chinensis. Acta Horticulturae, v.1204, p.65-76, 2018. DOI: https:// doi.org/10.17660/ActaHortic.2018.1204.9

SEO, S-G.; RYU, S-H.; ZHOU, Y.; KIM, S-H. Development of an efficient protocol for high-frequency regeneration system in Hibiscus syriacus L. Journal of Plant Biotechnology, v.44, n.2, p.164-170, 2017. DOI: https://doi.org/10.5010/JPB.2017.44.2.164

SOLANKI, P.; SIWACH, P. Optimization of conditions for in vitro seed germination and shoot multiplication of Aconitum heterophyllum Wall. International Journal of Medicinal and Aromatic Plants, v.2, n.3, p.481-487, 2012.
SULTANA. R.; QUADER, A.K.M.L.; HAQUE, M.; MAZUMDER, S.; PAUL, S.K. In vitro studies on shoot proliferation of kenaf (Hibiscus cannabinus L.). World Journal of Agricultural Sciences, v.12, n.1, p.25-30, 2016. DOI: http://www.idosi.org/wjas/wjas12(1)16/4.pdf

TAIZ, L.; ZEIGER, E.; MØLLER, I.M.; MURPHY, A. Plant Physiology and Development, 6ed. Massachusetts: Sinauer Associates Inc. Publishers, 2015. 761p.

YOUNESIKELAKI, F.S.; EBRAHIMZADEH, M.H.; DESFARDI, M.K.; BANALA, M.; MARKA, R.; NANNA, R.S. Optimization of seed surface sterilization method and in vitro seed germination in Althaea officinalis (L.) - an important medicinal herb. Indian Journal of Science and Technology, v.9, n.28, p.1-6, 2016. DOI: https://dx.doi. org/10.17485/ijst/2016/v9i28/90896 